\title{
Correction: The Epstein-Barr virus nuclear antigen-1 upregulates the cellular antioxidant defense to enable B-cell growth transformation and immortalization
}

\author{
Jiayu Wang ${ }^{1} \cdot$ Noemi Nagy $^{1} \cdot$ Maria G. Masucci $\mathbb{C}^{1}$ \\ Published online: 24 October 2019 \\ (c) The Author(s) 2019. This article is published with open access
}

\section{Correction to: Oncogene 38}

$$
\text { https://doi.org/10.1038/s41388-019-1003-3 }
$$

This article was originally published under Springer Nature's License to Publish, but has now been made available under a CC BY 4.0 license. The PDF and HTML versions of the paper have been modified accordingly.

Open Access This article is licensed under a Creative Commons Attribution 4.0 International License, which permits use, sharing,

adaptation, distribution and reproduction in any medium or format, as long as you give appropriate credit to the original author(s) and the source, provide a link to the Creative Commons license, and indicate if changes were made. The images or other third party material in this article are included in the article's Creative Commons license, unless indicated otherwise in a credit line to the material. If material is not included in the article's Creative Commons license and your intended use is not permitted by statutory regulation or exceeds the permitted use, you will need to obtain permission directly from the copyright holder. To view a copy of this license, visit http://creativecommons. org/licenses/by/4.0/.
The original article can be found online at https://doi.org/10.1038/ s41388-019-1003-3.

Maria G. Masucci

maria.masucci@ki.se

1 Department of Cell and Molecular Biology, Karolinska Institutet, Stockholm, Sweden 